\title{
In vitro Detection and Optimization of Streptokinase Production by Two Streptococcal Strains in a Relatively Low Cost Growth Medium
}

\author{
M. Abd El-Mongy and T. M. Taha* \\ Microbial Biotechnology Department, Genetic Engineering \& \\ Biotechnology Research Institute, Minufiya University, Sadat \\ City and *Botany \& Microbiology Dept., Faculty of Science, \\ AL-Azhar University, Assiut, Egypt.
}
7 HIS STUDY sought to demonstrate the optimization of streptokinase production. Enzyme production was monitored during the growth of both Streptococcus pyogenes and Streptococcus equisimilis in different media. Adjustment of the $\mathrm{pH}$ for culture media of $S$. pyogenes and $S$. equisimilis, every $12 \mathrm{hr}$ during incubation, significantly increased the enzyme production levels, when both microbes were grown on Strep-base medium.

The best carbon source for streptokinase production was glucose of both $S$. pyogenes and $S$. equisimilis, while mannitol and sorbitol were found to be less suitable carbon sources. Yeast extract, and casein could be used as the primary source of organic nitrogen for streptokinase production, when the microbes were allowed to grow on Strep-base medium. The highest levels of the enzyme production were obtained with $1.5 \%(\mathrm{w} / \mathrm{v})$ tryptone and $1.5 \%(\mathrm{w} / \mathrm{v})$ casein for $S$. equisimilis and $S$. pyogenes, respectively.

Detection of streptokinase produced was by the common casein digestion method and by the more sensitive chromozym substrate digestion method. Moreover, the enzyme was assayed electrochemically using the protamine-sensitive electrode to compare different methods of detection. Results obtained from electrochemical method were very close to that obtained with other methods. These results offer an alternative and reliable method for streptokinase detection during microbial growth. It provides a faster and less expensive technique for streptokinase determination especially when there is a need to detect the enzyme in turbid media.

Keywords: Streptokinase production, Streptococci, Rapid method, Streptokinase determination, Cheap media.

Streptokinase is an enzyme produced by streptococcus bacteria which is used in hospitals to dissolve the fibrin of blood clots, especially those in the arteries of the heart and lungs. It is also used on the clots formed in shunts during kidney dialysis. A fast-acting drug, streptokinase is most effective in dissolving newly-formed clots and is often released at the site of the clot via a catheter inserted into an artery.

E-mails: m_abdelmongy@yahoo.com tahery1@yahoo.com and 
Administered in the early stages of a heart attack to dissolve a clot in the coronary arteries (thrombosis), can reduce the amount of damage to heart muscle. Because excessive bleeding is a common side effect treatment is closely supervised. The drug is also used to treat wounds and ulcers in combination with another enzyme, streptodornase, for which use it is applied locally the SK-plasminogen complex is an efficient proteolytic activator of plasminogen. (Malke et al., 1984).

The blood clot or thrombus, which is the cause of strokes, consists of blood cells trapped in a matrix of the protein fibrin. Finding the cure for strokes and myocardial infarction has been taken into consideration since early decades of the twentieth century (Baruah et al., 2006). Anticoagulants have been used for treatment of myocardial infarction in the early 1940s, but this treatment was limited with no reduction in mortality rates in patients treated with oral administration of the drug (Wasserman et al., 1966). On the other hand, plasminogen activators were found to be the most effective drugs used in treatment of strokes and myocardial infarction (Collen et al., 1988; Francis \& Marder, 1991 and Zivin, 2009). Plasminogen activators are fibrinolytic agents that work by converting plasminogen to the natural fibrinolytic agent, consequently the produced plasmin lyses clot by breaking down the fibrinogen and fibrin contained in a clot (Feied \& Handler, 2004). Plasminogen activators can be classified into direct and indirect (Iqbal et al., 2002). Direct activators (e.g. tissue plasminogen activator) are highly specific limited serine proteases that directly cleave a single Arg 561-val 562 bond in the plasminogen molecule to yield plasmin (Baruah et al., 2006). Indirect plasminogen activators (e.g. streptokinase) are kinase enzymes that are mainly produced by bacteria but do not have proteolytic action. They forms a 1:1 stochiometric complex with plasminogen that can convert additional plasminogen to plasmin (Iqbal et al., 2002; Feied \& Handler, 2004; Banerjee et al., 2004).

Streptokinase is the most widely distributed plasminogen activator especially in the world's poorer health care system because of its low relative cost (Banerjee et al., 2004 and Feied \& Handler, 2004). The enzyme has a relatively long half-life period comparing to other plasminogen activators and it has a high affinity for circulatory plasminogen (Banerjee et al., 2004). The enzyme was first isolated in 1933 and entered clinical use in mid 1940s (Feied \& Handler, 2004).

It is an extracellular enzyme that is produced by various strains of b-hemolytic streptococci. It is a single-chain polypeptide with a molecular weight of $47 \mathrm{kDa}$ (Malke \& Ferretti, 1984 and Dubey et al., 2011) is made up of 414 amino acid residues (Malke \& Ferretti, 1984). The enzyme does not contain conjugated carbohydrates or lipids (Banerjee et al., 2004). Streptokinase has a multiple domains structure with $\alpha-\beta$ - and $\gamma$-domains. The three domains have different associated functional properties (Welfle et al., 1992). Gamma domain is essential for plasminogen activation (Wu et al., 2001), while $\beta$ domain is responsible for the formation of streptokinase-plasminogen complex which is in turn responsible for

Egypt. J. Microbiol. 47 (2012) 
activating the plasminogen (Banerjee et al., 2004). It has been found that the $\mathrm{N}$ terminal domain (residues 1-59) is responsible for the high plasminogen activation ability rather than the 60-414 amino acid residues domain of the protein (Nihalani et al., 1998). Moreover, streptokinase has an unstable secondary structure as well as a greatly reduced activity of the remaining enzyme fragment without these $\mathrm{N}$-terminal 1-59 amino acids residues (Young et al., 1995). Most of the streptokinases that are used as clot dissolving drugs are obtained from $\beta$-hemolytic streptococci especially those strains which are isolated from human origin as they lack erythrogenic toxins (Hagenson et al., 1989 and Wong et al., 1994).

Streptokinase determination depends on its ability to activate plasminogen to plasmin which in turn, hydrolyzes an indicator substrate and the extent of hydrolysis over a given period of time is related back to the concentration of streptokinase. Substrates for plasmin may include the fibrin clot, casein, other proteins, and various synthetic esters (e.g., lysine methyl ester, lysine ethyl ester, L-arginine methyl ester), which have been used successfully for the sensitive detection of the enzyme activity (Pratap \& Dikshit, 1998; Pratap et al., 2000 and Mundada et al., 2003). Radial caseinolysis method of agarose gel containing both casein and plasminogen is commonly used for simple detection of the enzyme (Saksela, 1981). The method is simple but it lacks accuracy and it is time consuming. Chromogenic detection for plasmin using the plasmin specific tripeptide H-D-valyl-leucyl-lysine-p-nitroaniline ((Kulisek et al., 1989; Wohl et al., 1980; Ringdahl et al., 1998 and Wang, S.G. et al., 1999) or, tosyl-glycylprolyl-lysine-4-nitroanilide (Wong et al., 1994 and Yazdani \& Mukherjee, 1998, 2002) has been reported as a sensitive method for enzyme assay. Plasmin activity could be determined electrochemically by detecting its proteolytic activity on the arginine-rich peptide protamine (Abd-Rabboh et al., 2003). The assay was based on the use of a macromolecule polycation/polyanion substrate; a complex of protamine and pentosan polysulfate (PPS), a highly sulfated polysaccharide. As plasmin cleaves the protamine within the complex, free PPS is generated and potentiometrically detected via a polyanion sensitive membrane electrode. The method could be used to detect streptokinase indirectly. The most desirable advantages of detecting the enzyme using biosensors are their accuracy, speed, and easy automation (Wang, 1999). These analytical devices give great promises in clinical and industrial applications.

Several attempts were made to increase streptokinase production by growing $\beta$-hemolytic streptococci on different media supplemented with various nutritional factors for growth (Hyun et al., 1997 and Patel et al., 2011), but commonly, the enzyme is produced from $\beta$-hemolytic streptococcal strains by growing cells on the rich complex Brain Heart Infusion (BHI) (Malke \& Ferretti, 1984), or Todd Hewitt (Vieira et al., 1998) media. In this work, we monitored the streptokinase production by two streptococcal strains in four different growth media and optimized some conditions for effective enzyme production, by the studied streptococcal strains, in relatively cheap medium. Comparison of different determination methods of streptokinase is also done. 


\section{Materials and Methods}

\section{Bacterial growth and streptokinase production}

Two bacterial strains, S. pyogenes ATCC 21548 and S. equisimilis ATCC 12388 , were used in this work as the source of extracellular streptokinase. Cells were activated by growing them overnight on Strep-base medium containing $10 \mathrm{~g}$ tryptone, $5 \mathrm{~g}$ yeast extract, $2 \mathrm{~g} \mathrm{~K}_{2} \mathrm{HPO}_{4}, 5 \mathrm{~g} \mathrm{NaCl}$, and $5 \mathrm{~g}$ glucose per liter. The $\mathrm{pH}$ was adjusted to 7.4 by the addition of $1 \mathrm{~N} \mathrm{NaOH}$. Cultures were grown under $100 \mathrm{rpm}$ shaking conditions at $37^{\circ} \mathrm{C}$. One $\mathrm{ml}$ of the previously grown cultures was used to inoculate $100 \mathrm{ml}$ of the different media used for enzymatic production. Cultures were grown under $100 \mathrm{rpm}$ shaking conditions at $37^{\circ} \mathrm{C}$. Growth was monitored by measuring the absorbance at $600 \mathrm{~nm}$ (Ko et al., 1995), which was very much correlated with the number of viable cells count. At the indicated time $1.5 \mathrm{ml}$ of each of the growing cultures was taken and centrifuged in a microcentrifuge at 7,000 rpm for $2 \mathrm{~min}$. The supernatants were used as a crude sample to measure the activity of streptokinase enzyme.

To monitor streptokinase production by both $S$. pyogenes and $S$. equisimilis grown on different microbiological media, the same previous procedure was carried out to inoculate Brain Heart Infusion medium (BHI), Todd-Hewitt medium, Blood Base medium, and Strep-base medium.

\section{Effect of pH on streptokinase production during growth}

Both $S$. pyogenes and $S$. equisimilis were activated over night by growing them on Strep-base medium at $37^{\circ} \mathrm{C}$ with shaking at $100 \mathrm{rpm}$. For each bacterium, a hundred $\mathrm{ml} \mathrm{BHI} \mathrm{medium} \mathrm{was} \mathrm{inoculated} \mathrm{with} \mathrm{one} \mathrm{ml}$ of the previously activated culture. Growth curve and streptokinase production were monitored by taking samples at the desired time intervals. At the indicated time, a sample was taken for $\mathrm{pH}$ measurement. The $\mathrm{pH}$ of the growing culture was adjusted by the addition of $5 \mathrm{~N} \mathrm{NaOH}$.

\section{Effect of different carbon sources on streptokinase production}

Strep-base medium was used to study the effect of different carbon sources on streptokinase production by both $S$. pyogenes and $S$. equisimilis. Sucrose, glucose, mannitol, sorbitol, and lactose were used as pure soluble sugars for supplement of primary carbon source in the medium. Sugars were supplemented at concentrations of $2.5 \mathrm{~g}, 5 \mathrm{~g}$, and $10 \mathrm{~g}$ per liter. Modified Strep-base contained $10 \mathrm{~g}$ tryptone, $5 \mathrm{~g}$ yeast extract, $2 \mathrm{~g} \mathrm{~K}_{2} \mathrm{HPO}_{4}, 5 \mathrm{~g} \mathrm{NaCl}$, and appropriate weight of sugar under investigation per liter. The $\mathrm{pH}$ was adjusted to 7.4 by the addition of $1 \mathrm{~N} \mathrm{NaOH}$.

Effect of different organic nitrogen sources on streptokinase production

Strep-base medium was used to study the effect of different organic nitrogen sources on streptokinase production by both $S$. pyogenes and S. equisimilis. Tryptone, yeast extract, peptone, casein, and beef extract were used as the

Egypt. J. Microbiol. 47 (2012) 
primary source of organic nitrogen in the medium at concentrations of $5 \mathrm{~g}$ and $10 \mathrm{~g}$ per liter. Modified Strep-base contained $2 \mathrm{~g} \mathrm{~K}_{2} \mathrm{HPO}_{4}, 5 \mathrm{~g} \mathrm{NaCl}$, and $5 \mathrm{~g}$ glucose and appropriate weight of the organic nitrogen source under investigation per liter. The $\mathrm{pH}$ was adjusted to 7.4 by the addition of $1 \mathrm{~N} \mathrm{NaOH}$.

\section{Determination of enzyme activity}

Casein digestion method

Streptokinase activity was determined indirectly with casein digestion method, which is based on the determination of the liberated tyrosine from digested casein after plasminogen activation (Mounter \& Shipley, 1957). Activity was determined according to a modified method of Sutar et al. (1986). Reaction mixture $(2 \mathrm{ml})$ containing $10 \mathrm{mg}$ casein, $50 \mathrm{mM}$ Tris- $\mathrm{HCl}$, $\mathrm{pH} 8.0$, containing $0.1 \mathrm{ml}$ (or an appropriate dilution) of supernatants. The reaction was carried out at $37^{\circ} \mathrm{C}$ for 20 min then it was terminated by the addition of $2.6 \mathrm{ml}$ $5 \% \mathrm{w} / \mathrm{v}$ trichloroacetic acid (TCA) and $0.4 \mathrm{ml} 3.3 \mathrm{M} \mathrm{HCl}$. Reactions were then kept on ice for $30 \mathrm{~min}$ after which they were filtered using Whatman paper \#1. The absorbance of the TCA soluble fractions were measured at $280 \mathrm{~nm}$. Units of enzyme activity were calculated with a standard SK curve.

\section{Chromozym activity test}

Streptokinase activity was determined by the colorimetric method with N-ptosyl-glycyl-prolyl-lysine-p-nitroanilide acetate (Chromozym PL; Boehringer) as the substrate for Plasmin enzyme (Wong et al., 1994 and Yazdani \& Mukherjee, 2002). Samples were mixed with Plasminogen and the mixture was incubated at $37^{\circ} \mathrm{C}$ for about $5 \mathrm{~min}$. The substrates mixture containing the chromozym dissolved in $50 \mathrm{mM}$ Tris- $\mathrm{HCl}$ buffer $\mathrm{pH} 8.0$ was then added to the enzymesubstrate mixture. The reaction was incubated for $20 \mathrm{~min}$ at $37^{\circ} \mathrm{C}$ and the change in absorbance at $405 \mathrm{~nm}$ was monitored at $37^{\circ} \mathrm{C}$ by using a spectrophotometer. Units of enzyme activity were calculated with a standard streptokinase curve.

\section{Electrochemical assay of streptokinase}

Three separate DNNS-based protamine-sensitive membrane electrodes were used simultaneously to monitor the initial decrease in protamine levels (Chang et al., 1999). Experiments were performed by adding $5 \mu \mathrm{l}$ of a $5 \mathrm{mg} / \mathrm{ml}$ protamine (Sigma, St. Louis, MO) solution to $1 \mathrm{ml}$ of Tris working buffer (50 mM Tris and $120 \mathrm{mM}$ $\mathrm{NaCl}, \mathrm{pH}$ 7.4). After reaching a steady-state/ non-equilibrium response (3 min), $100 \mu \mathrm{l}$ of a preincubated $(5 \mathrm{~min})$ sample of centrifuged bacterial culture solution $(40 \mu \mathrm{l})$, human plasminogen $(0.45 \mathrm{U}$, Sigma), all in Tris working buffer. The decrease in the EMF response toward protamine was monitored over a 5-min period by each of the sensors. A calibration plot for streptokinase was constructed by graphing the initial rate of the potential decrease, in $\mathrm{mV} / \mathrm{min}$ against streptokinase activity, in IU/ml sample. 


\section{Preparation of polycation-sensitive electrode}

Protamine-sensitive membrane electrodes were prepared according to the method described by Ramamurthy et al. (1998). Electrochemical EMF measurements were made vs an $\mathrm{Ag} / \mathrm{AgCl}$ reference electrode using a VF-4 (World Precision Instruments, Sarasota, FL). Sensors were calibrated for protamine by adding different concentrations of $1 \mathrm{mg} / \mathrm{ml}$ protamine solution, to $4.9 \mathrm{ml}$ of Tris- $\mathrm{HCl}$ buffer with continuous stirring of the test solution at a constant rate. The EMF changes of the membrane electrodes were measured 2 min following each sequential addition of protamine solution, at which time the non-equilibrium steady-state potential had been reached. Calibration curves were plotted using the net potential change from the baseline value $(\triangle \mathrm{EMF})$ versus the concentration of the polycation.

\section{Protein determination}

Protein concentrations in different fractions were determined as described by (Bradford, 1976). Protein content was measured at $595 \mathrm{~nm}$ using a spectrophotometer. A standard curve was made using Bovine serum albumin as a standard protein. Blank reagent was $100 \mu \mathrm{l}$ of the propitiate buffer and $5 \mathrm{ml}$ of protein reagent.

\section{Results}

Streptokinase production in different growth media by two streptococcal strains. These two strains show a Beta hemolysis which is caused by one or more streptolysins (Wolef \& Liljemark, 1978). To monitor the enzyme production during the bacterial growth curve of both strains, they were grown on different media. Brain Heart Infusion (BHI) (Malke \& Ferretti, 1984 and Gase et al., 1995) and Todd-Hewitt (Vieira et al., 1998 and Caballero et al., 1999) are both specific media that have been used in several reports for cultivation of streptococci and streptokinase production. Streptokinase reached 88.5 units per $\mathrm{ml}$ when S. pyogenes was grown on BHI medium (streptokinase unit is the amount of streptokinase that catalyzes the production of $1 \mu \mathrm{mol}$ of plasmin from plasminogen in one minute at standard conditions). Specific activity reached 27.48 units per mg protein and remained over 20 units per mg protein for $24 \mathrm{hr}$ of cultivation. A similar result was observed when S. pyogenes was grown on Todd-Hewitt medium; the production level was 85.12 units after $7 \mathrm{hr}$ of cultivation. Specific activity also reached a maximum level of 28.74 units per $\mathrm{mg}$ protein with a steady state pattern over $15 \mathrm{hr}$ of cultivation (Table 1). Streptokinase production level was 91.6 units per $\mathrm{ml}$ and 85.2 units per $\mathrm{ml}$ (Table 1) when S. equisimilis was grown on BHI and Todd-Hewitt media, respectively. The high level of production remained over 80 units per $\mathrm{ml}$ along the incubation period for both media. The specific activity of the produced enzyme reached over 30 units per $\mathrm{mg}$ protein for both cultures. Production patterns of streptokinase when both $S$. pyogenes and $S$. equisimilis are grown on previous media are shown in Fig. 1.

Egypt. J. Microbiol. 47 (2012) 
TABLE 1. Streptokinase production during growth of $S$. pyogenes and $S$. equisimilis grown on BHI and Todd-Hewitt media

\begin{tabular}{|c|c|c|c|c|}
\hline \multirow{2}{*}{$\begin{array}{l}\text { Incubation } \\
\text { time (hr.) }\end{array}$} & \multicolumn{2}{|c|}{$\begin{array}{c}\text { Streptokinase production } \\
\text { (U/mg protein), S. pyogenes } \\
\text { grown on }\end{array}$} & \multicolumn{2}{c|}{$\begin{array}{c}\text { Streptokinase production } \\
\text { (U/mg protein), } \text { S. equisimilis } \\
\text { grown on }\end{array}$} \\
\cline { 2 - 5 } & BHI & Todd-Hewitt & BHI & Todd-Hewitt \\
\hline 0 & 0.87 & 1.15 & 0.28 & 3.75 \\
\hline 0.5 & 2.92 & 13.82 & 7.87 & 2.64 \\
\hline 1 & 12.01 & 22.36 & 21.04 & 7.46 \\
\hline 2 & 20.94 & 25.17 & 31.73 & 15.88 \\
\hline 3 & 26.48 & 26.87 & 32.55 & 24.33 \\
\hline 4 & 26.04 & 27.74 & 34.57 & 31.25 \\
\hline 5 & 24.6 & 26.29 & 31.04 & 29.63 \\
\hline 6 & 22.41 & 23.85 & 31.75 & 27.55 \\
\hline 8 & 23.56 & 21.54 & 28.34 & 25.05 \\
\hline 10 & 23.44 & 21.52 & 24.87 & 24.28 \\
\hline 12 & 23.42 & 22.18 & 26.15 & 22.35 \\
\hline 14 & 24.31 & 22.84 & 22.91 & 21.3 \\
\hline 15 & 21.06 & 21.19 & 20.93 & 19.45 \\
\hline 24 & 19.35 & 17.14 & 21.08 & 19.19 \\
\hline
\end{tabular}
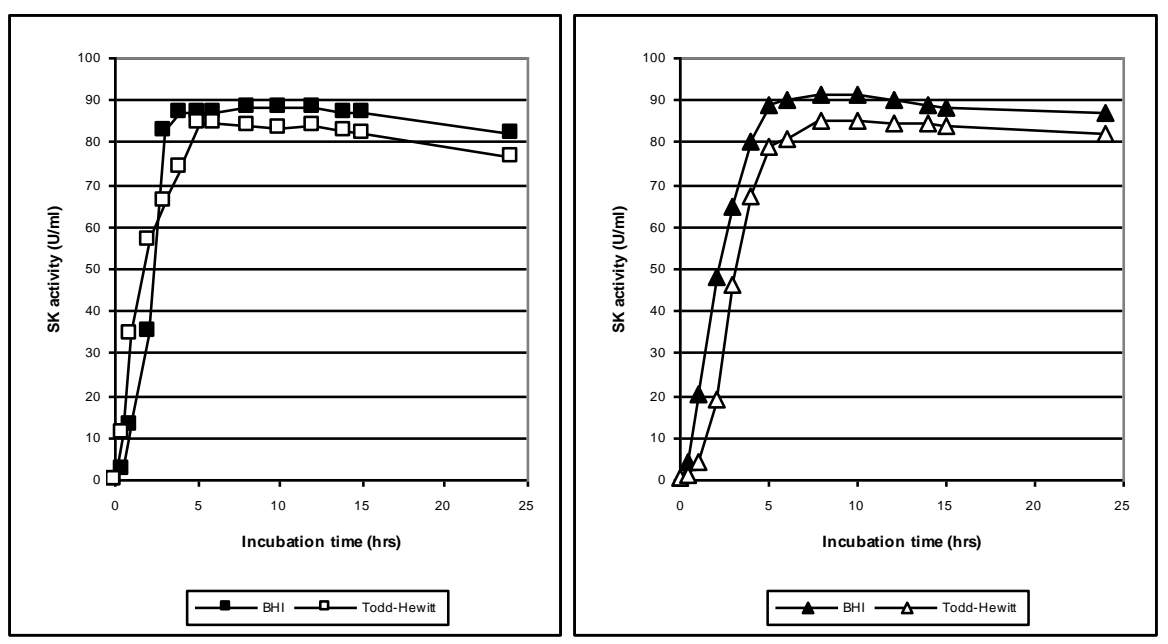

Fig. 1. Streptokinase production during growth of (a) S. pyogenes and (b) S. equisimilis. 
S. pyogenes and S. equisimilis are streptokinase hyperproducing streptococcal strains (Steiner \& Malke, 2002 and Banerjee et al., 2004).

In an attempt to produce streptokinase from $S$. pyogenes and $S$. equisimilis using relatively inexpensive media, Strep-base and blood base media were used for the microbial growth. When S. pyogenes was grown on Strep-base medium, its enzymatic production did not reach its maximum activity at the end of the exponential phase like it did upon growing the microbe on BHI medium. The maximum enzyme production was relatively low, 54.96 units per ml (Table 2). On the other hand, streptokinase production reached 74.3 units per ml (Table 2) when $S$. pyogenes was grown on Blood base media. Specific activity reached 31.70 units per mg protein in Blood base medium (i.e., the specific activity values are too close to that obtained upon growing the bacterium on BHI and Todd Hewitt media). The enzyme production was relatively low (40.82 units per $\mathrm{ml}$ ) when $S$. equisimilis was grown on Strep-base medium (Table 2), but the production level reached 83.07 units per $\mathrm{ml}$ when the microbe was grown on Blood-base medium. The specific activity for streptokinase in blood base medium exceeds 29 units per mg protein (Table 2). Streptokinase production patterns when both $S$. pyogenes and $S$. equisimilis are grown on previous media are shown in Fig. 2.

TABLE 2. Streptokinase production during growth of $S$. pyogenes and $S$. equisimilis on Strep-base and blood base media.

\begin{tabular}{|c|c|c|c|c|}
\hline \multirow{2}{*}{$\begin{array}{l}\text { Incubation } \\
\text { time (hr) }\end{array}$} & \multicolumn{2}{|c|}{$\begin{array}{c}\text { Streptokinase production } \\
\text { U/mg protein), S. pyogenes } \\
\text { grown on }\end{array}$} & \multicolumn{2}{c|}{$\begin{array}{c}\text { Streptokinase production } \\
\text { U/mg protein), S. equisimilis } \\
\text { grown on }\end{array}$} \\
\cline { 2 - 5 } & Strep-base & Blood base & Strep-base & Blood base \\
\hline 0 & 0.54 & 0.44 & 0.36 & 0.01 \\
\hline 0.5 & 1.98 & 6.16 & 0.1 & 5.63 \\
\hline 1 & 2.41 & 23.42 & 5.55 & 12.06 \\
\hline 2 & 7.78 & 27.40 & 7.05 & 21.85 \\
\hline 3 & 15.78 & 30.80 & 7.35 & 27.29 \\
\hline 4 & 19.09 & 29.18 & 14.98 & 27.20 \\
\hline 5 & 21.72 & 27.58 & 13.55 & 28.87 \\
\hline 6 & 19.77 & 25.65 & 13.21 & 28.09 \\
\hline 8 & 16.82 & 25.64 & 13.07 & 24.35 \\
\hline 10 & 15.06 & 22.56 & 11.88 & 23.17 \\
\hline 12 & 15.09 & 19.77 & 11.66 & 24.55 \\
\hline 14 & 15.22 & 17.44 & 11.50 & 22.33 \\
\hline 15 & 13.66 & 16.87 & 11.67 & 21.82 \\
\hline 24 & 13.07 & 14.85 & 9.87 & 20.18 \\
\hline
\end{tabular}

Egypt. J. Microbiol. 47 (2012) 

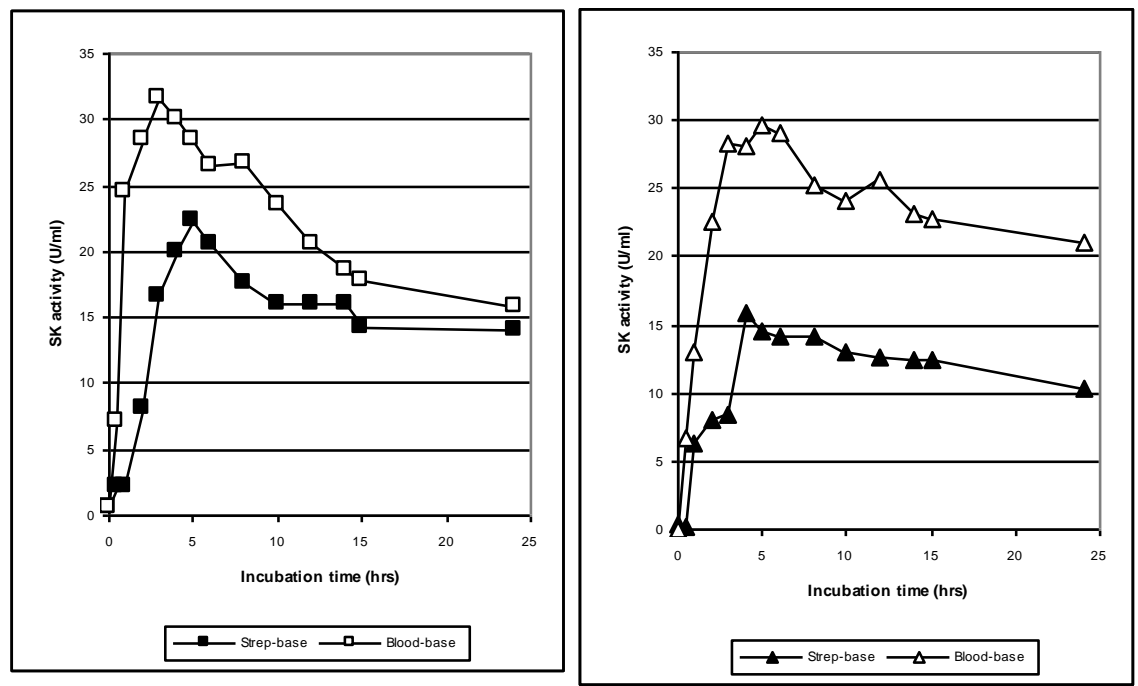

Fig. 2. Streptokinase production during growth of (a) S. pyogenes and (b) S. equisimilis.

Effect of pH on streptokinase production during bacterial growth

Streptokinase production by both $S$. pyogenes and S. equisimilis was greatly affected by the change of the medium $\mathrm{pH}$ during the growth of the microbes. Samples were taken from all cultures after three days of incubation, the measured $\mathrm{pH}$ in all samples ranged from 5.6 to 6.1; that drop of $\mathrm{pH}$ may affect the bacterial growth as well as the SK production. Acidification of the medium occurs as a result of bacterial growth and metabolic consumption of sugars found in the medium (Mickelson, 1964). When the $\mathrm{pH}$ was adjusted every $12 \mathrm{hr}$ for both $S$. pyogenes and $S$. equisimilis grown on Strep-base medium, streptokinase production was almost doubled at the end of the $72 \mathrm{hr}$ of incubation (Table 3). These results suggest a longer and more controllable production of the enzyme if both $S$. pyogenes and $S$. equisimilis are allowed to grow in a continuous fermentation system.

TABLE 3. Effect of $\mathrm{pH}$ on streptokinase production by $S$. pyogenes and $S$. equisimilis.

\begin{tabular}{|c|c|c|c|c|}
\hline \multirow{2}{*}{$\begin{array}{l}\text { Incubation } \\
\text { time (hr) }\end{array}$} & \multicolumn{2}{|c|}{ S. pyogenes SK activity (U/ml) } & \multicolumn{2}{c|}{ S. equisimilis SK activity (U/ml) } \\
\cline { 2 - 5 } & $\begin{array}{c}\text { Without pH } \\
\text { adjustment }\end{array}$ & $\begin{array}{c}\text { With pH } \\
\text { adjustment }\end{array}$ & $\begin{array}{c}\text { Without pH } \\
\text { adjustment }\end{array}$ & $\begin{array}{c}\text { With pH } \\
\text { adjustment }\end{array}$ \\
\hline 24 & 55.33 & 52.48 & 44.32 & 42.7 \\
\hline 48 & 37.15 & 47.43 & 29.78 & 37.56 \\
\hline 72 & 21.44 & 40.43 & 18.75 & 34.22 \\
\hline
\end{tabular}

Both microbes were grown on Strep-base medium to the indicated time.

$\mathrm{pH}$ was adjusted every $12 \mathrm{hr}$ of incubation by $5 \mathrm{~N} \mathrm{NaOH}$

The final $\mathrm{pH}$ value in the adjusted flasks was 7.4. 
Effect of different carbon sources on streptokinase production during bacterial growth

Streptokinase production by both $S$. pyogenes and $S$. equisimilis was significantly affected by the carbon source found in the medium. Maximum production of the enzyme was obtained when both microbes were grown on Strep-base medium in which $0.5 \mathrm{~g} \%$ glucose was used as the sole source of carbon. The enzyme production was not supported by using $0.5 \mathrm{~g} \%$ mannitol or sorbitol as the primary source of carbon (Table 4). Streptokinase production remained high even when a low concentration of glucose $(0.25 \mathrm{~g} \%)$ was used. However, a higher concentration of glucose $(1 \mathrm{~g} \%)$ did not help in improving the production level of the enzyme in both cultures.

TABLE 4. Effect of carbon source on streptokinase production by $S$. pyogenes and $S$. equisimilis.

\begin{tabular}{|l|c|c|c|c|c|c|}
\hline \multirow{2}{*}{ Carbon source } & \multicolumn{3}{|c|}{ S. pyogenes SK activity (U/ml) } & \multicolumn{3}{c|}{ S. equisimilis SK activity (U/ml) } \\
\cline { 2 - 7 } & $\mathbf{0 . 2 5 g} \%$ & $\mathbf{0 . 5 g} \%$ & $\mathbf{1 g} \%$ & $\mathbf{0 . 2 5 g} \%$ & $\mathbf{0 . 5 g} \%$ & $\mathbf{1 g} \%$ \\
\hline Sucrose & 8.5 & 8.3 & 5.6 & 8.6 & 6.4 & 3.7 \\
\hline Glucose & 53.4 & 52.8 & 48.6 & 39.2 & 43.5 & 34.7 \\
\hline Mannitol & 0.0 & 0.2 & 0.0 & 0.0 & 0.0 & 0.0 \\
\hline Sorbitol & 0.2 & 0.2 & 0.0 & 0.0 & 0.0 & 0.0 \\
\hline Lactose & 18.6 & 16.7 & 11.3 & 25.2 & 23.6 & 17.6 \\
\hline
\end{tabular}

*Cultures were grown at $37^{\circ} \mathrm{C}$ using the indicated media composition.

*Enzyme activity represents $(\mathrm{U} / \mathrm{ml})$ measured in samples taking after the end of the exponential phase.

Effect of different organic nitrogen sources on streptokinase production during bacterial growth

Both $S$. pyogenes and S. equisimilis were grown on Strep-base medium which contained different sources of organic nitrogen. Generally, $1.5 \mathrm{~g} \%$ of organic nitrogen gave the highest SK production in both cultures (Table 5). Both casein and yeast extract supported a high level of enzyme production when $S$. pyogenes was grown on the modified Strep-base medium suggesting that these two sources of organic nitrogen could be used as replacement for tryptone in the original Strep-base medium.

S. equisimilis gave the highest SK production upon growing on Strep-base medium supplemented with $1.5 \mathrm{~g} \%$ tryptone (Table 5). 
TABLE 5. Effect of organic nitrogen source on streptokinase production by $S$. pyogenes and $S$. equisimilis.

\begin{tabular}{|l|c|c|c|c|c|c|}
\hline \multirow{2}{*}{$\begin{array}{c}\text { Organic } \\
\text { nitrogen source }\end{array}$} & \multicolumn{3}{|c|}{ S. pyogenes SK activity (U/ml) } & \multicolumn{3}{c|}{ S. equisimilis SK activity (U/ml) } \\
\cline { 2 - 7 } & $\mathbf{0 . 5 g} \%$ & $\mathbf{1 g} \%$ & $\mathbf{1 . 5} \mathbf{g} \%$ & $\mathbf{0 . 5 g} \%$ & $\mathbf{1 g} \%$ & $\mathbf{1 . 5 g} \%$ \\
\hline Tryptone & 37.4 & 40.3 & 53.4 & 30.12 & 33.6 & 42.16 \\
\hline Yeast extract & 26.23 & 33.24 & 52.21 & 12.14 & 17.17 & 33.24 \\
\hline Peptone & 17.25 & 23.17 & 27.29 & 10.4 & 14.3 & 18.5 \\
\hline Casein & 36.7 & 38.6 & 56.16 & 29.13 & 37.24 & 40.12 \\
\hline Beef extract & 23.23 & 32.18 & 44.7 & 16.8 & 27.9 & 29.3 \\
\hline
\end{tabular}

*Cultures were grown at $37^{\circ} \mathrm{C}$ using the indicated media composition.

*Enzyme activity represents $(\mathrm{U} / \mathrm{ml})$ measured in samples taking after the end of the exponential phase.

\section{Detection of streptokinase}

To monitor enzymatic activity during growth of the microbe, detection method should be fast and accurate. Streptokinase assay with radial caseinolytic activity is one of the oldest methods used for this purpose (Saksela, 1981). The method depends on direct measurement of the area of the transparent lysis zone in an agarose-casein plate that contains plasminogen. Although it is relatively inexpensive method, it is slow and can not be used to monitor the enzyme activity in short time intervals. It was used mainly for the qualitative determination of the enzyme, but for an accurate and quantitative method for streptokinase assay, other methods were used. The enzyme was assayed upon growing bacterial strains on different media by the common casein digestion method (Muller et al., 1989) and the more sensitive Chromozym substrate digestion method (Wong et al., 1994) (Fig. 3). The two methods are based on detecting the amidolytic activity of plasmin - librated after plasminogen activation by streptokinase - upon synthetic chromogenic substrates (Chang et al., 1999). Although these methods are accurate and reliable, they are expensive and their total reaction time is relatively high.

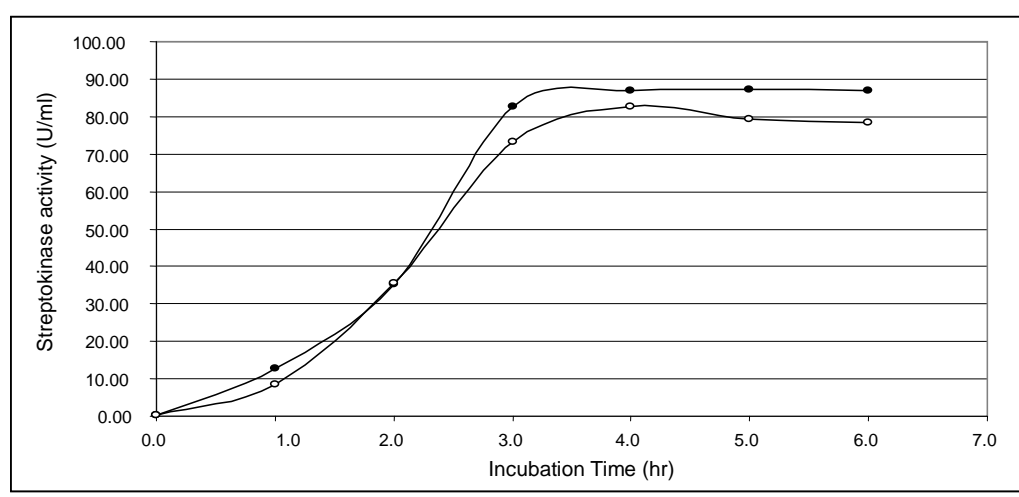

Fig. 3. Streptokinase production when $S$. pyogenes was grown on BHI medium. Enzyme was assayed with Chromozym substrate method $(\bullet)$ and casein digestion method (०), respectively 
Assaying streptokinase with electrochemical detectors, such as polymer membrane-based ion-selective electrodes offers a number of advantages over spectrophotometric methods especially in cases where samples are highly colored or turbid like bacterial cultures. Protamine-sensitive membrane electrodes have been used to measure trypsin activity (Yun et al., 1995). Protamine is an arginine-rich protein which is known to be an excellent substrate to proteases (Ong \& Johnson, 1976). Polyion-sensitive electrodes have a high response towards protamine, but smaller polycationic fragments formed after the action of plasmin on protamine can not be detected by these electrodes (Chang et al., 1999).

Streptokinase activity can be detected by measuring the initial rate of decrease in the potentiometric response of the polycation-sensitive membrane electrode towards protamine degradation by the action of librated plasmin. Figure 4 shows the average potentiometric responses of tubular dinonylnaphthalene sulfonate (DNNS)-based protamine-sensitive membrane electrodes toward $25 \mu \mathrm{g} / \mathrm{ml}$ protamine and the effect of adding increased concentrations of standard streptokinase. Enzyme samples were first incubated with plasminogen for $5 \mathrm{~min}$.

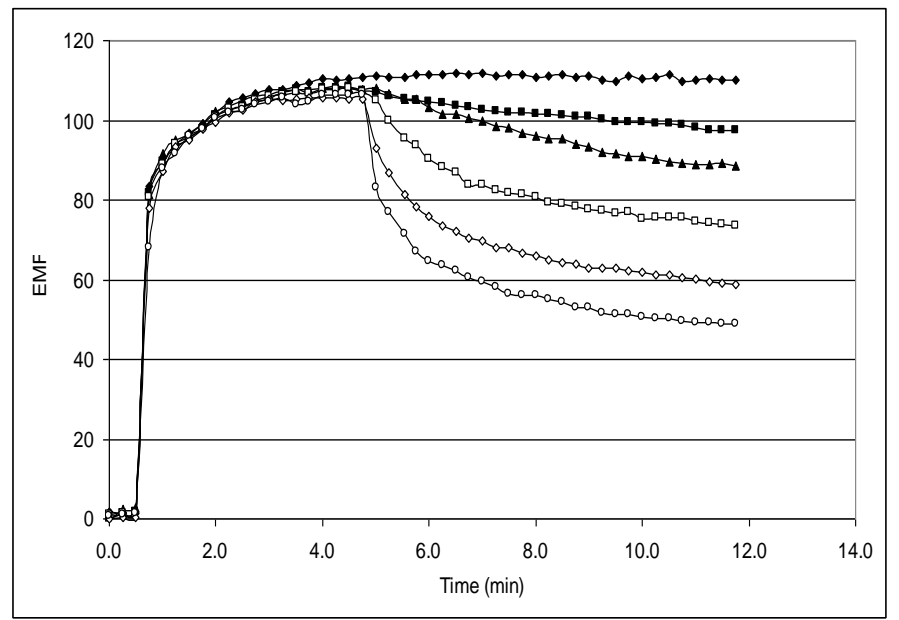

Fig. 4. Potentiometric response of (DNNS)-based protamine-sensitive membrane electrodes towards $25 \mu \mathrm{g} / \mathrm{ml}$ protamine and subsequent addition of $100 \mu \mathrm{l}$ of standard streptokinase.

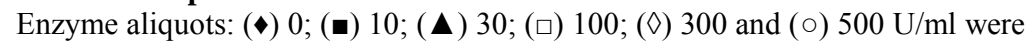
preincubated with plasminogen for $5 \mathrm{~min}$ at room temperature.

Monitoring bacterial streptokinase production polycation-sensitive electrode

To assay for streptokinase during microbial growth using the protamine-sensitive electrode, S. pyogenes and S. equisimilis were grown on $\mathrm{BHI}$ medium at $37^{\circ} \mathrm{C}$ and at different time intervals, samples were taken to be tested for streptokinase activity. To compare between different methods of detection, enzyme assay was carried out with both electrochemical and spectrophotometric methods. Figure 5 shows response of the protamine-sensitive electrode to streptokinase samples - taken at different time intervals - during growth of S. pyogenes.

Egypt. J. Microbiol. 47 (2012) 


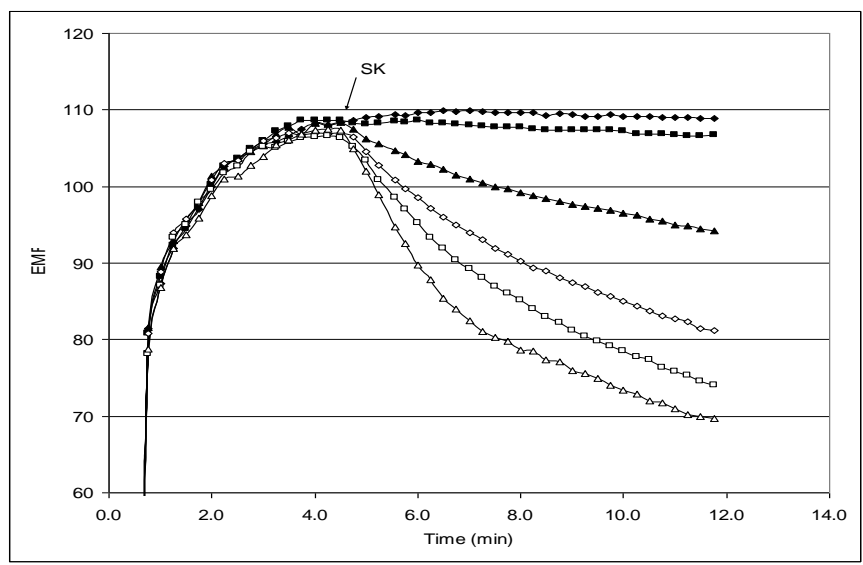

Fig. 5. Potentiometric response of (DNNS)-based protamine-sensitive membrane electrodes towards $25 \mu \mathrm{g} / \mathrm{ml}$ protamine and subsequent addition of $100 \mu \mathrm{l}$ of cell-free bacterial culture after growing $S$. pyogenes on $\mathrm{BHI}$ medium at $37^{\circ} \mathrm{C}$

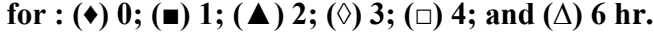

Samples were preincubated with plasminogen for $5 \mathrm{~min}$ at room temperature.

Results obtained from electrochemical method were so close to that obtained from the traditional spectrophotometric method when both S. pyogenes and $S$. equisimilis (Table 6) were tested for their streptokinase activity during bacterial growth. These results offer an alternative and reliable method for streptokinase detection during microbial growth.

TABLE 6. Streptokinase detection during $S$. pyogenes and $S$. equisimilis growth with both Protamine-sensitive electrode and spectrophotometric methods.

\begin{tabular}{|c|c|c|c|c|}
\hline \multirow[b]{2}{*}{$\begin{array}{c}\text { Incubation } \\
\text { time (hr) }\end{array}$} & $\begin{array}{c}\text { S. pyogenes } \\
\text { activity }(\mathrm{U} / \mathrm{ml})\end{array}$ & Streptokinase & $\begin{array}{l}\text { S. equisimilis } \\
\text { activity }(\mathrm{U} / \mathrm{ml})\end{array}$ & Streptokinase \\
\hline & $\begin{array}{l}\text { Protamine- } \\
\text { sensitive } \\
\text { electrode } \\
\text { method }\end{array}$ & $\begin{array}{c}\text { Chromozym } \\
\text { substrate } \\
\text { method }\end{array}$ & $\begin{array}{c}\text { Protamine- } \\
\text { sensitive } \\
\text { electrode } \\
\text { method }\end{array}$ & $\begin{array}{c}\text { Chromozym } \\
\text { substrate } \\
\text { method }\end{array}$ \\
\hline 0 & 0 & 0 & 0 & 0 \\
\hline 1 & 6.15 & 5.27 & 4.53 & 3.09 \\
\hline 1.5 & ND & ND & 10.31 & 9.74 \\
\hline 2 & 19.19 & 17.88 & 21.05 & 20.22 \\
\hline 2.5 & 41.34 & 44.09 & 39.93 & 39.3 \\
\hline 3 & 55.68 & 53.87 & 52.33 & 51.24 \\
\hline 3.5 & 734.06 & 71.23 & 70.54 & 72.56 \\
\hline 4 & 82.05 & 84.29 & 84.09 & 85.92 \\
\hline
\end{tabular}

Microbes were grown on $\mathrm{BHI}$ at $37^{\circ} \mathrm{C}$ and at time intervals, samples were centrifuged at $8000 \mathrm{~g}$ for $2 \mathrm{~min}$ then, cell-free supernatants were tested for the streptokinase activity. 


\section{Discussion}

Streptokinase is one of the most important enzymes produced by certain streptococci strains. This enzyme is used as a treatment for stroke and myocardial infarction. Decreasing the production costs of this enzyme is a strong demand for many users all over the world as it will make this effective treatment for such dangerous diseases in the reach of poor patients. Optimization the production process is the first step toward decreasing the production costs. In this work we used two strains, S. pyogenes ATCC 21548 and S. equisimilis ATCC 12388 , for enzyme production. These strains were grown on four different media, Brain Heart Infusion medium (BHI), Todd-Hewitt medium, Blood Base medium, and Strep-base medium. When streptococci strains were cultured in the first two media, they produced much enzyme, however these media are expensive. In Stripe-base which is relatively cheap medium, enzyme production was weak. In this work we tried to improve the enzyme productivity in the relatively cheap Stripe-base medium by some trials such as adjusting $\mathrm{pH}$ and selecting the optimum concentrations of carbon and nitrogen sources.

The results showed that, enzyme production in the adjusted cultures did not dramatically decreased as that without $\mathrm{pH}$ adjustment and after three days the enzyme activities of the adjusted cultures were as much as duple of the non adjusted cultures. These results match the results obtained by Babashamsi (Babashamsi et al., 2009) and also suggested the efficiency of continues fermentation method, whereby the $\mathrm{pH}$ value will be maintained optimum along the production process, for enzyme production. Fortunately, low concentration $(0.25 \%)$ glucose was superior over other carbon sources for enzyme production. These results suggest that, the fed-batch fermentation method will be more suitable for supplying the carbon source for efficient enzyme production. Concerning the organic nitrogen sources, results showed that high concentration 1.5\% of both casein and yeast extract as well as tryptone were suitable organic nitrogen sources for enzyme production by the two studied streptococcal strains. These results suggested that the set-batch fermentation process is more suitable for supplying the organic nitrogen source for the enzyme production.

Monitoring the enzyme activity during the enzyme production process plays a very important role for efficient enzyme production. Finding reliable, easy, fast and cheap method for streptokinase detection in bacterial culturing broth will facilitate monitoring and consequently improve production process. There are many methods for detection of streptokinase, such as casein digestion method (Muller et al., 1989) and the more sensitive Chromozym substrate digestion method (Wong et al., 1994). Although these methods are accurate and reliable, their total reaction time is relatively long and cannot be used to monitor the enzyme activity in short time intervals. The electrochemical detectors, such as polymer membrane-based ionselective electrodes are easy, fast, and relatively cheap methods for streptokinase assay. In this study the ion-selective electrode assaying method compared to the more sensitive Chromozym method, the results showed complete accordance between the two methods. These results confirmed the reliability of the ion-selective electrode assaying method.

Egypt. J. Microbiol. 47 (2012) 


\section{Conclusion}

In conclusion, S. pyogenes ATCC 21548 and S. equisimilis ATCC 12388 can be used for streptokinase production in the relatively cheap Stripe-base medium. Results recommended continues fermentation process at which glucose as sole carbon source, is supplied by fed-batch technique, while organic nitrogen source and other nutrients can be supplied by the set-batch. The fast, easy, and cheap ion selective electrode is a reliable assaying method for detecting the enzyme production activity along the fermentation process. Using such conditions will lead to much enzyme production with lower costs depending on the price of the medium.

\section{Referrences}

Abd-Rabboh, H.S.M., Nevins, S.A., Nedime, N. and Meyerhoff, M.E. (2003) Electrochemical assay of protease activities based on polycation/polyanion complex as substrate and polyion sensitive membrane electrode detection. Biosens. Bioelectron. 18, 229-236.

Babashamsi, M., Razavian, H. M. and Najadmoghaddam, M. R. (2009) Production and purification of streptokinase by protected affinity chromatography. Avicenna J. Med. Biotechnol. 1, 47-51.

Banerjee, A., Chisti, Y. and Banerjee, U.C. (2004) Streptokinase-a clinically useful thrombolytic agent. Biotechnol. Adv. 22, 287-307.

Baruah, D.B., Dash, R.N., Chaudhari, M.R. and Kadam, S.S. (2006) Plasminogen activators: A comparison. Vascular Pharmacology, 44, 1-9.

Bradford, M. M. (1976) A rapid and sensitive method for the quantitation of microgram quantities of protein utilizing the principle of protein-dye binding. Anal Biochem. 72, 248-254.

Chang, L.C., Meyerhoff, M.E. and Yang, V.C. (1999) Electrochemical assay of plasminogen activators in plasma using polyion-sensitive membrane electrode detection. Anal. Biochem. 276, 8-12.

Collen, D., Stump, D.C. and Gold, H.K. (1988) Thrombolytic therapy. Annu. Rev. Med. 39, 405- 423.

Dubey, R., Kumar, J., Agrawala, D., Char, T. and Pusp, P. (2011) Isolation, production, purification, assay and characterization of fibrinolytic enzymes (Nattokinase, Streptokinase and Urokinase) from bacterial sources. African J. Biotechnol. 10, 1408-1420.

Feied, C. and Handler, J.A. (2004) Thrombolytic therapy. www.emedicine. com/emerg/ topic831.htm, Dated 12.03.2005.

Francis, C.W. and Marder, V.J. (1991) Fibrinolytic therapy for venous thrombosis. Prog. Cardiovasc. Dis. 34(3), 193-204. 
Gase, K., Ellinger, T. and Malke, H. (1995) Complex transcriptional control of the streptokinase gene of Streptococcus equisimilis H46A. Mol. Gen. Genet. 247, 749-58.

Hagenson, M.J., Hoiden, K.A., Parker, K.A., Wood, P.J., Cruze, J.A., Fuke, M., Hopkins, T.R. and Stroman, D.W. (1989) Expression of streptokinase in Pichia pastoris yeast. Enzyme Microb. Technol. 11, 650-656.

Holmstrom, B. (1968) Production of streptokinase in continuous culture. Appl Microbiol. 16,73-77.

Hyun, H.H., Lee, Y.B., Song, K.H., Jeon, J.Y. and Lee, H.H. (1997) Strain improvement for enhanced production of streptokinase and streptodornase in Streptococcus sp. J. Microbiol Biotechnol. 7,101 -106.

Iqbal, O., Tobu, M., Demir, M., Fareed, J., Aziz, S. and Messmore, H. (2002) The role of thrombolytic drugs in the management of acute myocardial infarction and stroke. Turk. J. Haematol. 19, 151-177.

Ko, J.H., Park, D.K., Kim, I.C., Lee, S.H. and Byun, S.M. (1995) High-level expression and secretion of streptokinase in Escherichia coli. Biotechnol. Lett. 17,1019-1024.

Kulisek, E.S., Holm, S.E. and Johnston, K.H. (1989) A chromogenic assay for the detection of plasmin generated by plasminogen activator immobilized on nitrocellulose using a paranitroanilide synthetic peptide substrate. Med. Anal. Biochem. 177, pp. $78-84$.

Malke, H. and Ferretti, J.J. (1984) Streptokinase: cloning, expression and excretion by Escherichia coli. Proc. Natl. Acad. Sci. USA. 81, pp. 3557-3561.

Mickelson, M.N. (1964) Chemically defined medium for growth of Streptococcus pyogenes. J. Bacteriol. 88, 158-164.

Mounter, L.A. and Shipley, B.A. (1957) The inhibition of plasmin by toxic phosphorus compounds. J. Biol. Chem. 226, 855-861.

Muller, J., Reinert, H. and Malke, H. (1989) Streptokinase mutations relieving Escherichia coli K-12 (prlA4) of detriments caused by the wild-type $s k c$ gene. $J$. Bacteriol. 171, 2202-2208.

Mundada, L.V., Prorok, M., DeFord, M.E., Figuera, M., Castellino, F.J. and Fay, W.P. (2003) Structure-function analysis of the streptokinase amino terminus (residues 1-59). J. Biol. Chem. 278, 24421-24427.

Nihalani, D., Kumar, R., Rajagopal, K. and Sahni, G. (1998) Role of the aminoterminal region of streptokinase in the generation of a fully functional plasminogen activator complex probed with synthetic peptides. Protein Sci. 7, 637-648.

Ong, E.B. and Johnson, A.J. (1976) Protamine, a substrate for thrombolytic agents and enzymes of similar specificity. Anal Biochem. 75, 568-582.

Patel, V.P., Patel K.S. and Patel, R.M., (2011) Isolation and optimization of streptokinase production by batch fermentation. International J. Pharm. Biol. Arch. 2,1488-1492.

Egypt. J. Microbiol. 47 (2012) 
Pratap, J. and Dikshit, K.L. (1998) Effect of signal peptide changes on the extracellular processing of streptokinase from Escherichia coli : requirement for secondary structure at the cleavage junction. Mol. Gen. Genet. 258, 326-333.

Pratap, J., Rajamohan, G. and Dikshit, K.L. (2000) Characteristics of glycosylated streptokinase secreted from Pichia pastoris : enhanced resistance of SK to proteolysis by glycosylation. Appl. Microbiol. Biotechnol. 53, 469-475.

Ramamurthy, N., Baliga, N., Wahr, J.A., Schaller, U., Yang, V.C. and Meyerhoff, M.E. (1998) Improved protamine-sensitive membrane electrode for monitoring heparin concentrations in whole blood via protamine titration. Clin. Chem. 44, 606613.

Ringdahl, U., Svensson, M., Wistedt, A. C., Renné, T., Kellner, R., Müller-Esterl, W. and Sjöbring, U. (1998) Molecular co-operation between protein PAM and streptokinase for plasmin acquisition by Streptococcus pyogenes. J. Biol. Chem. 13, 6424-6430.

Saksela, O. (1981) Radial caseinolysis in agarose: a simple method for detection of plasminogen activators in the presence of inhibitory substances and serum. Anal. Biochem. 111, 276-282.

Sutar, I.I., Vartak, H.G., Srinivasan, M.C. and Siva Raman, H. (1986) Production of alkaline protease by immobilized mycelium of Conidiobolus. Enzyme Microb. Technol. 8, 632-634.

Vieira, V.V., Teixeira, L.M., Zahner, V., Momen, H., Facklam, R.R., Steigerwalt, A.G., Brenner, D.J. and Castro, A.C.D. (1998) Genetic relationships among the different phenotypes of Streptococcus dysgalactiae strains. Int. J. Sys. Bacteriol. 48, 1231-1243.

Wang, J. (1999) Amperometric biosensors for clinical and therapeutic drug monitoring: a review. J. Pharm. Biomed. Anal. 19, 47-53.

Wang, S. G., Reed, G. L. and Hedstrom, L. (1999) The deletion of Ile1 changes the mechanism of streptokinase: evidence for the molecular sexuality hypothesis. Biochemistry, 38, 5232-5240.

Wasserman, A.J., Gutterman, L.A., Yoe, K.B., Kemp, V.E. and Richardson, D.W. (1966) Anticoagulants in acute myocardial infarction. The failure of anticoagulants to alter mortality in a randomized series. Am. Heart J. 71, 43-49.

Welfle, K., Pfeil, W., Misselwitz, R., Welfle, H. and Gerlach, D. (1992) Conformational properties of streptokinase-differential scanning calorimetric investigations. Int. J. Biol. Macromol. 14, 19-22.

Wohl, R. C., Summaria, L. and Robbins, K.C. (1980) Kinetics of activation of plasminogen by different activator species at $\mathrm{pH} 7.4$ and $37^{\circ} \mathrm{C}$. J. Biol. Chem. 255, 2005-2013.

Wolef, L. and Liljemark, W.F. (1978) Observation of Beta-hemolysis among three strains of Streptococcus mutants. Infect Immun. 19, 745-748.

Egypt. J. Microbiol. 47 (2012) 
Wong, S.L., Ye, R. and Nathoo, S. (1994) Engineering and production of streptokinase in a Bacillus subtilis expression-secretion system. Apll .Environ. Microbiol. 60, 517523.

Wu, D.H., Shi, G.Y., Chuang, W.J., Hsu, J.M., Young, K.C., Chang, C.W. and Wu, H.L. (2001) Coiled coil region of streptokinase gamma domain is essential for plasminogen activation. J. Biol. Chem. 276, 15025-15033.

Yazdani, S.S. and Mukherjee, K.J. (2002) Continuous-culture studies on the stability and expression of recombinant streptokinase in Escherichia coli. Bioprocess Biosyst. Eng. 24, 341-346.

Young, K.C., Shi, G.Y., Chang, Y.F., Chang, B.I., Chang, L.C., Lai, M.D., Chuang W.J. and Wu, H.L. (1995) Interaction of streptokinase and plasminogen-studied with truncated streptokinase peptides. J. Biol. Chem. 270, 29601-29606.

Yun, J.H., Meyerhoff, M.E. and Yang, V.C. (1995) Protamine-sensitive polymer membrane electrode: characterization and bioanalytical applications. Anal. Biochem. 224, 212-220.

Zivin, J.A. (2009) Acute stroke therapy with tissue plasminogen activator (tPA) since it was approved by the U.S. Food and Drug Administration (FDA). Annals of Neurol. 66, 6-10.

(Received 23/11/2011; accepted 10/5/2012) 


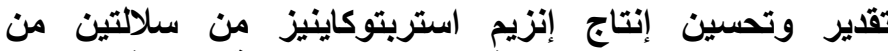 الاستربتوكوكاي على وسط غذائي منخفض التكلفة نسبيا في المعمل من}

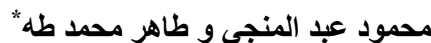

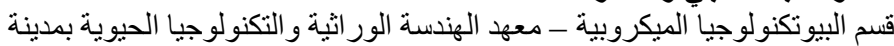

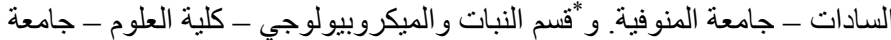

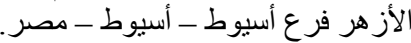

يعتبر إنزيم استربتوكاينيز من الإنزيمات ذات الأهمية الكبيرة في المجال الطبي

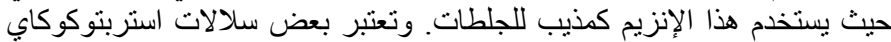

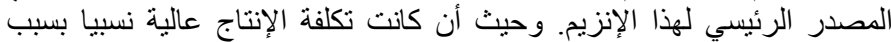

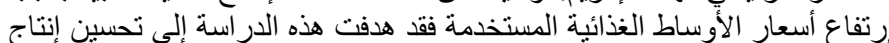

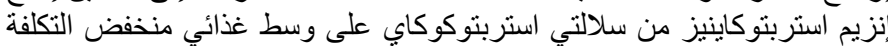
السبيا وكذلك إيجاد وسيلة سريعة لتقديرة في أوساط النمو حتى يسكهل متابعة عملية

ولقد أوضحت النتائج زيادة انتاجية الإنزيم من سلالتي استربتوكوكاي

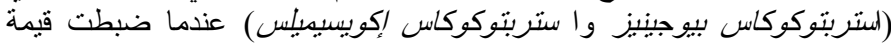

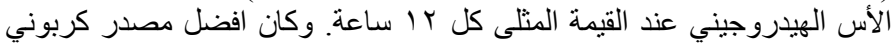

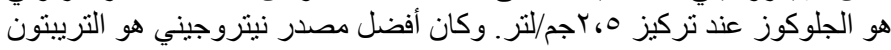

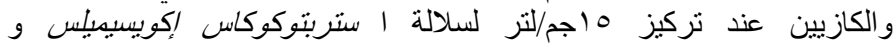

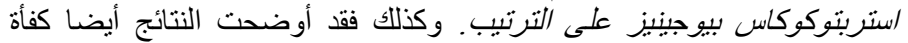

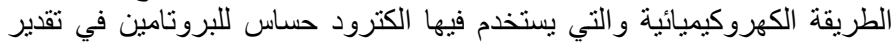

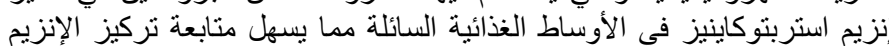

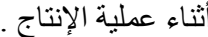

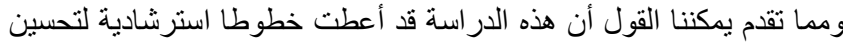

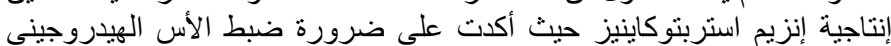

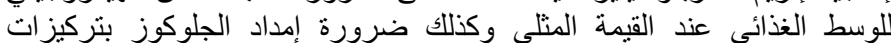
منخفضة بصورة منصلة اثناء عملية الإنتاج. 